\title{
International Collaboration for Women in IT: How to Avoid Reinventing the Wheel
}

\author{
Annemieke Craig \\ School of Information Systems \\ Deakin University, Melbourne, \\ Victoria, Australia
}

\author{
Catherine Lang \\ Faculty of ICT, \\ Swinburne University of \\ Technology, Victoria, Australia \\ clang@groupwise.swin.edu.au
}

\begin{abstract}
This paper uses information contributed by ACM-W Ambassadors from nine countries to build a picture of women working to improve the gender balance in IT around the world. The focus on women's participation in education, the workforce and the political arena is presented using Hofstede and Hofstede's (2005) dimensions of cultural masculinity, power distribution and individuality for each of the ACM-W Ambassador countries to set the scene. It is apparent from this compilation of information that different social and cultural climates in many parts of the world will necessitate different actions by ACM-W Ambassadors in their respective countries. While the ACM-W Ambassador program provides a forum for ideas, support and strategies to deal with the under-representation of women in IT, many of the current Ambassadors have more pressing issues to deal with, and indeed a 'one size for all' model for programs to promote IT to women will not be suitable. Exploring the network from an Australian perspective this work demonstrates that much is to be gained from increasing international networks to share the strategies and support required to encourage more women into IT.
\end{abstract}

Keywords: Gender, female, computing, under-representation, networking

\section{Introduction}

In many western countries, Australia included, the information technology (IT) workforce continues to be male dominated (Klawe, Whitney, \& Simard, 2009; Nielsen \& Von Hellens, 2006).

The ACM Women's Council (ACM-W) in the ACM (the largest educational and scientific computing society in the world) is supporting women in IT worldwide through its Ambassador program. The Ambassador program enables women to serve as the ambassador for a particular country. The program then enables the sharing of information, strategies and statistics amongst the group, as well as the wider community. These ACM-W ambassadors, while having much in

Material published as part of this publication, either on-line or in print, is copyrighted by the Informing Science Institute. Permission to make digital or paper copy of part or all of these works for personal or classroom use is granted without fee provided that the copies are not made or distributed for profit or commercial advantage AND that copies 1) bear this notice in full and 2) give the full citation on the first page. It is permissible to abstract these works so long as credit is given. To copy in all other cases or to republish or to post on a server or to redistribute to lists requires specific permission and payment of a fee. Contact 0HPublisher@InformingScience.org to request redistribution permission. common in their enthusiasm to promote IT to other women, have different social, political and economic challenges that complicate the international push to increase female involvement in IT. This paper will present an international picture that highlights both commonalities and differences in the quest to promote gender equity and affirmative action in IT. It presents the current social situation of working women through an Aus- 
tralian lens. The status and membership of women's groups in IT professional bodies in the US and Australia are discussed before presenting a twenty-first century snapshot of women in education, government and IT from each of the nine ACM-W Ambassador countries. This snapshot is enhanced by cultural dimensions related to masculinity, power and individualism (Hofstede \& Hofstede, 2005). While it is impossible to find one solution for the under-representation of women in IT around the globe, working together enables the sharing of strategies, which can be modified to suite different political and social contexts.

\section{The Social Context}

Clearly, any research in this field needs to take changing social and educational contexts into account. In many parts of the world women have now:

...grown up in a time when gender equity is both taken for granted and not yet a reality. These women enter [institutions]...in which they still find traces of the old prejudices, but also substantial efforts to correct them. In their classes they still encounter aggressive men, but now also find assertive women and sensitive teachers who challenge the old patterns of interaction. (Derek Bok Institute, 1996, p. 1)

Particularly in western countries participation of women in many areas of the workforce has been increasing since the 1950s. Yet, careers and jobs in the IT arena are still clearly seen as a masculine domain. Charles and Bradley (2006) identified the degree of choice given to young women as a factor to them fulfilling traditional cultural stereotypes. "For women in affluent societies, freedom of choice ... implies both the right to be free from overt discrimination (should they elect to pursue a traditionally male-dominated field of study) and the right to choose poorly paid femalelabeled career paths, if they so desire" (Charles \& Bradley, 2006, p.196). It was found that countries that prevented students from choosing preferences during their secondary education had a greater gender balance in computer related courses at university. In some western countries where students selected courses early in their school years it was suggested that young girls self-selected what they perceived to be 'gender-appropriate' options. So, while we can applaud gender equity in education and the work force, covert social and cultural factors continue to influence student choice.

Employment statistics in Australia indicate that while there have been major inroads to female participation in education and the workforce, there are still strong culturally embedded stereotypes associated with gender. In 1954 women made up only $23 \%$ of the total labor force (OFW, 2004 ) but by 2006 women accounted for almost half (45\%) of the labor force (ABS, 2007a). Over the same period of time there was remarkable growth in new employment opportunities in the emerging IT industry. However, this industry did not manage to attract equal numbers of women and men, and currently women account for about one fifth of the Australian IT workforce (Maslog-Levis, 2005). Women are paid less than men in similar positions in this sector and are less likely to hold senior management positions (Byrne \& Staehr, 2003). Women are also still the primary homemakers and those most likely to work reduced hours to accommodate family values. A comparison of male and female professionals found that 'where part-time and hourly contract work exists, it is much more likely the incumbent will be a female professional'(APESMA, 2004). It appears that despite our belief in equality, the role of women has not changed over time as they are still expected to be the primary homemakers. A survey of employment status by professional discipline reported that females in IT were three times more likely than their male colleagues to be working part-time (APESMA, 2004).

The legal and political landscape has undergone considerable change in Australia during the last century. By 1908 Australian women from all states had won the right to vote, although aboriginal 
women had to wait until 1967 (Watkins, Rueda, \& Rodriguez, 1999). In 1909 the Australian Women's Political Association was founded which campaigned for equal pay and equal rights. Sixty years later the landmark Equal Pay Case was finally decided by the Arbitration Commission; that of 'equal pay for equal work' which was to be phased in over three years (Salvano, 1993). However in practice, because of the restrictive interpretation of the meaning of 'equal work' only $18 \%$ of women in the workforce were receiving equal pay by 1972 (Deery \& Plowman, 1985).

A second Arbitration Commission hearing in 1972, adopted the principle of 'equal pay for work of equal value'. As a consequence the ratio of female to male average weekly fulltime earnings has risen to $83.7 \%$ in 2007 (ABS, 2007a). However in $200746 \%$ of female employees worked part-time compared with $15 \%$ of male employees (ABS, 2007b). The disparity in pay rates for equal work implies that subtle and perhaps covert discrimination may still be at play.

In the 1950s the norm in Australian society was that men were bread-winners and women were care-givers (Probert, 2002). Probert (2002) argued that the situation has now become much more complex with a dominant view that women should be part of the workforce but there are no clear ideas about how children should be cared for. Hakim (2000, p. 82) argued that women in the twenty-first century now have "real choices as to how to live their lives;" however, much of the literature suggests that career outcomes for women are still influenced by social and institutional constraints that women encounter throughout their careers (Cockburn 1991; Crompton \& Jones, 1984; Eveline 1996; Poole \& Langan-Fox, 1997). Allen, Castleman, Coulthard, and Reed (2002) suggest that modern day access to contraception and the implementation of equal opportunity policies have not removed the dilemmas or difficulties faced by women wanting a career. Summers (2003) concurs and argues that despite the rhetoric of equality, and the successes of many individual women, for many women there has been a decline in their economic physical and social wellbeing over the last decade. This is a situation faced by women across the entire spectrum of careers in the workforce including those women in IT careers.

\section{Professional Context: ACM, ACS, \& Ambassador Program}

The path for women in IT to gain full professional acknowledgement has not always been smooth. The ACM was founded in 1947 in the US and today has approximately 89,000 members (Feldman, 2009). It was not till 1992 that the ACM's Committee on Women in Computing (ACM-W) was set up as a full committee and not only a special interest group. This committee had a mission to "celebrate, inform and support women in computing and improve their working and learning environments." This mission indicated that the ACM recognised a need for affirmative action in the women in IT arena. The ACM-W committee (amongst many other activities) initiated an international program in 1999 by establishing contacts through Ambassadors in various countries around the world. In 2008 the ACM-W committee was elevated to ACM-W Council and chartered to raise the awareness and interest in gender diversity across all ACM activities (Feldman, 2009).

The ACM-W has taken steps to build an international scope on women in computing via the Ambassador Program. An Ambassador, who may be from academia or industry, is selected due to their commitment and profile of working to encourage gender diversity in their country. The ambassador's duties are to provide information to ACM-W on issues related to women in computing such as the programs and conferences in operation in their country. In 2008 there were nine Ambassadors in geographically dispersed countries.

In Australia, the relevant professional body, the ACS (Australian Computing Society) recognised women as a 'Special Interest Group' up until 2005. Then after considerable petitioning from 
women the ACS-W was elevated to the status of a Board with full voting rights. The establishment of the ACM-W by the ACM was not an insignificant argument within the preceding debate and discussions.

Spencer (2006) highlighted the unique position that these boards provide working within professional IT societies to "challenge the dominant paradigms of the profession." This cannot be done without males in IT taking on some of the responsibility for addressing the decreasing diversity in the IT discipline, and not just "allocate responsibility for action and all concern about genderinclusiveness to women's committees and boards" (Spencer, 2006). This is a valid point for western countries where the political and cultural context necessitates the role of women in IT to act as evangelists obliged to undertake the role of champion for the IT profession as well their own gender. However in some of the Ambassador countries equality of access to education is a more pressing issue. The data provided in the next section reports on the current state of women in computing from the ACM-W Ambassador countries. While the ACM-W and its Ambassador program has made significant progress in some areas, this data highlights the varying political, educational and access priorities that each face in their respective countries.

\section{Women and IT around the Globe in the $21^{\text {st }}$ Century}

Trauth, Quesenberry, and Yeo (2006, p. 279) argue it is important to consider the context of women's experiences to challenge the 'prevailing tendency to generalize from one dataset to all women, everywhere'. The status of women in society varies from country to country. Equally within countries there can be variation from state to state and from region to region depending upon cultural, institutional and political attitudes as well as socio-economic factors. Level of literacy, access to education, and representation within the political arena can give some indication of the position women hold within a society.

Around the world $17 \%$ of all parliamentary seats were held by women in 2006 , a $50 \%$ increase from $11.3 \%$ in 1995 (IPU, 2007). In 2006 women were a critical mass (30\% or more) in decisionmaking positions in a total of 19 parliaments including Rwanda (48.8\%), Costa Rica (38.6\%) and the Netherlands (33\%). Providing only one statistic from Nordic countries $(40.8 \%)$ hides the fact that women in Sweden now hold $47.3 \%$ of parliamentary seats, the second highest percentage in the world (IPU, 2007).

Consequently the following figures are offered to provide a picture of the ACM-W ambassador's country, while acknowledging that internal localized differences will still be present. However as Dr. Hilary Rose argues, "Statistics are central, the word comes from 'numbers for the state'. If you wish to have policy, you have to have competent statistics. No statistics, no problem, no policy. You just get gestures. Statistics help identify problems and can monitor the effectiveness of remedies" (European Commission, 2003).

Table 1 presents a picture of women's education as well as women's participation in IT education at universities, the paid workforce, the IT workforce and government. The literacy levels of women in India, Pakistan and Turkey indicate that priorities should be around equalizing access and involvement of women in education as a whole, and IT can be used as an enticing enabler in these countries. The statistics also indicate that western nations with almost $100 \%$ female literacy (Australia, Canada, US and UK) may be able to learn from a country like Pakistan, where female literacy rates are low yet this does not preclude strong female representation in government (33\%). In all the Ambassador's countries women constitute more than a third of the student body at universities, with females in the majority in four of the nine countries. The same proportional representation is not evident in female enrolments in IT degree courses. Perusing the level of literacy, access to education, and representation with the political arena can give some indication of the position women hold within societies. 
Table 1: A picture of women's participation in education, workforce IT and Politics as reported by ACM-W Ambassadors 2008

\begin{tabular}{|c|c|c|c|c|c|c|}
\hline Country & $\begin{array}{c}\text { Population } \\
\text { Literacy Lev- } \\
\text { els }\end{array}$ & $\begin{array}{c}\% \\
\text { University } \\
\text { students } \\
\text { women }\end{array}$ & $\begin{array}{c}\% \\
\text { Women in } \\
\text { IT @ uni- } \\
\text { versity }\end{array}$ & $\begin{array}{c}\% \text { of } \\
\text { Women in } \\
\text { paid work- } \\
\text { force }\end{array}$ & $\begin{array}{c}\% \text { of } \\
\text { Women in } \\
\text { IT work- } \\
\text { force }\end{array}$ & $\begin{array}{c}\% \\
\text { Women } \\
\text { in } \\
\text { Govt. }\end{array}$ \\
\hline Australia & Total: $100 \%$ & $55 \%$ & $20.0 \%$ & $45.0 \%$ & $21.0 \%$ & $26.5 \%$ \\
\hline Canada & Total: $99 \%$ & $59 \%$ & $18.0 \%$ & $47.0 \%$ & $27.4 \%$ & $20.8 \%$ \\
\hline India & $\begin{array}{l}\text { Total: } 65 \% ; \\
\text { M: } 75 \% \text { F: } 54 \%\end{array}$ & $37 \%$ & $\mathrm{n} / \mathrm{a}$ & $38.0 \%$ & $22.0 \%$ & $9.0 \%$ \\
\hline New Zealand & Total: $100 \%$ & $49 \%$ & $25.0 \%$ & $47.0 \%$ & $\mathrm{n} / \mathrm{a}$ & $32.0 \%$ \\
\hline Pakistan & $\begin{array}{l}\text { Total: } 46 \% \text { M: } \\
60 \% \text { F: } 31 \%\end{array}$ & $50 \%$ & $\mathrm{n} / \mathrm{a}$ & $28.0 \%$ & $\mathrm{n} / \mathrm{a}$ & $33.0 \%$ \\
\hline South Africa & $\begin{array}{l}\text { Total: } 86 \% \text { M: } \\
87 \% \text { F: } 86 \%\end{array}$ & $56 \%$ & $34.4 \%$ & $42.8 \%$ & $18.6 \%$ & $32.8 \%$ \\
\hline Turkey & M: 99\% F: 92\% & $42 \%$ & $31.0 \%$ & $39.6 \%$ & $30.0 \%$ & $4.4 \%$ \\
\hline $\begin{array}{l}\text { United } \\
\text { Kingdom }\end{array}$ & Total: $99 \%$ & $50 \%$ & $23.0 \%$ & $46.0 \%$ & $16.0 \%$ & $19.5 \%$ \\
\hline $\begin{array}{l}\text { United States } \\
\text { of America }\end{array}$ & Total: $97 \%$ & $57 \%$ & $25.0 \%$ & $47.0 \%$ & $\mathrm{n} / \mathrm{a}$ & $14.0 \%$ \\
\hline
\end{tabular}

To gain a greater understanding of localized variations in culture and politics Hofstede and Hofstede (2005) completed a cultural profile of many of the world's countries.

Table 2: A picture of the country, its workforce and politics

\begin{tabular}{|l|c|c|c|}
\hline \multicolumn{1}{|c|}{ Country } & $\begin{array}{c}\text { Masculinity } \\
\text { (MAS) }\end{array}$ & $\begin{array}{c}\text { Power Distance } \\
\text { (PDI) }\end{array}$ & $\begin{array}{c}\text { Individualism } \\
\text { (IDV) }\end{array}$ \\
\hline Australia & 61 & 36 & 90 \\
\hline Canada & 52 & 39 & 80 \\
\hline India & 56 & 77 & 48 \\
\hline New Zealand & 58 & 22 & 77 \\
\hline Pakistan & 50 & 55 & 14 \\
\hline South Africa & 63 & 49 & 65 \\
\hline Turkey & 45 & 66 & 37 \\
\hline United Kingdom & 66 & 35 & 91 \\
\hline United States of America & 62 & 40 & \\
\hline
\end{tabular}

When this cultural profile is added to the information provided by the ACM-W ambassadors a broader picture of each of the countries emerges. We provide three aspects of Hofstede's analysis in Table 2, the first of which is the Masculinity (MAS) index. A high score in this index indicates that in general this country values masculine assertive values; 'the masculine countries are some- 
what assertive and competitive ... these countries show a gap between men's values and women's values'(Hofstede \& Hofstede, 2005, p.132). The key differences between masculine and feminine societies are that challenge, earnings, recognition and advancement are important traits to society in general. In masculine societies, according to these authors, men should be assertive, ambitious and tough; boys play to compete, as opposed to girls who play together; girls cry but boys don't; fathers deal with facts while mothers with feelings (Hofstede \& Hofstede, 2005 p.132). The MAS index for the group of Ambassador's countries shows that the UK (66) is the most masculine, slightly in front of the US and Australia, and the country at the most feminine end of the spectrum is Turkey (45).

The second indicator is the Power Distance Index (PDI) which 'suggests that a society's level of inequality is endorsed by the followers as much as by the leaders' (Hofstede \& Hofstede, 2005, p. 45). A low PDI indicates a society with a greater degree of shared responsibilities between the sexes. A large PDI score indicates that inequalities among people are expected and desired. The less powerful people should be dependent, parents teach children obedience and students give teachers respect even outside class. For the countries represented by Ambassadors the highest PDI is for India (77), the lowest for New Zealand (22).

The final indicator is the degree of individualism (IDV) in a society. It is considered that in societies with a high score in this indicator, the success of the individual outweigh the success of the wider community (Hofstede \& Hofstede, 2005, p.105). In the individualist countries personal time, freedom of choice and challenge in employment are important. At the other end of the spectrum, collectivist societies indicated by a low IDV index, training opportunities to improve skills, good working conditions and full use of skills are the important factors. The USA has the highest IDV score (91) and is closely followed by Australia (90). From within the Ambassadors countries Pakistan scored lowest (14). It is considered that generally Eastern cultures have a much lower IDV score due to their cultural values of collectivism over individualism (Trauth, 2002).

A varied picture emerges from this twenty-first century snapshot. Pakistan has a much lower percentage of their population in the paid work-force, yet greater female representation in parliament than Australia, Canada, UK and US. Turkey has the largest proportion of females in the IT workforce yet only $4.4 \%$ representation in parliament. The UK and USA value masculine traits to a much greater degree than Pakistan or Turkey, yet the level of inequality between the sexes is greater in Turkey, and the greatest inequality of all in India. It should also be kept in mind that these differences are a factor of cultural relativism and that "no one culture is best or worst, and there are no scientific standards or moral rights' (Hofstede \& Hofstede, 2005, p.120). These indicators are presented to provide a greater insight into different cultural priorities and are the result of non-judgmental investigations. Critics of Hofstede are acknowledged, however the authors present the data to give a 'macro' view of each culture.

When these factors are considered it is clear that priorities for ACM-W Ambassadors in the UK, US and Australia may be similar, focusing on attracting women who have wide choices, while those of the Ambassadors of India, Pakistan and Turkey are grounded more in access and education issues, as well as equality of the sexes. Female literacy levels are varied in these locations.

\section{No Need to Reinvent the Wheel}

The Ambassador program was set up to encourage more women into IT around the world, yet it has become apparent that the situations faced in many parts of the world will necessitate different actions and strategies. In South Africa, the US, Canada, UK and Australia for example the priority area is to invalidate the masculine cultural stereotype associated with the industry, however in India, the priority is empowerment via IT and access to all forms of education, including IT education. Despite this, there is a similar problem in each of these countries, how to encourage more 
women to take up IT. While the different cultures, political, social and educational systems suggest that there needs to be different priorities making one solution impossible to find, a group such as this provides support, contact and community in a diverse world.

From an Australian perspective for example, much has been learnt and shared through the collaboration that the program has facilitated:

- Connections made possible by the network of ambassadors enabled the 'Computer Clubs for Girls' initiative in the UK to be explored and then adapted to suit the Australian environment. The Australian Research Council (ARC) has funded a three year project to pilot its delivery in Australian schools.

- University curriculum developed by the Ambassador from the US teaches all students about the gender imbalance in IT and its implications for the future of the discipline. These curriculum documents have been shared so that they could be offered in Australia and elsewhere.

- Panel sessions have been conducted at almost all the Grace Hopper Conferences. These panels have varied from presentations by 3 to 8 ambassadors. They have focused on awareness raising and resource sharing. A panel presentation was also given by 5 of the ambassadors at ITiCSE 2007.

- Other aspects of the possible steps to greater female involvement in IT have been shared enabling implementation in the Australian context. For example Alice and paired programming have been implemented in some Australian schools.

- Contacts made through the program have facilitated the invitation of high profile international keynote speakers to local conferences.

- The personal aspect of the ambassador program should also not be undervalued. Having the network of ambassadors to help each other to act not as an isolated person but to enable contact through the distributed network. For the Australian ambassador for example the contacts made through the program have broadened the network of both industry and academic contacts. This has enabled sponsorship of events and collaborative projects not previously possible.

- Lastly, the value of an international network of women working towards the same mission cannot be under-estimated. It empowers individuals who may be a lone voice in their institution or region.

\section{Conclusion - One Size Does Not Fit All}

Cultural factors influence female literacy levels in south Asian countries, yet in western industrialised societies, where women have greater access to education, they are less likely than women in Asia to get involved at the machinations of government and therefore be less likely to influence political decisions. There appears to be a universal acceptance that IT is male that extends across western industrialized cultures (Suriya \& Craig, 2003). A recently published study assessed the degree of over-representation of males in IT (Charles \& Bradley, 2006). Australia rated at 2.86 in this study, more than the US (2.10) but less than the UK (3.10). It would appear that we all have a long and involved road ahead before we can achieve a critical mass of women in IT.

While the equality of men and a woman in many societies is not yet a reality nor is it in the world of IT. The IT industry has been a masculine domain for many years and the Ambassador Program cannot hope to reverse the situation in just ten years, however the support Ambassadors provide to each other enables the work to continue.

In Australia women have many career choices presented to them, a luxury not always available in other cultures. Women are embracing IT applications yet not IT careers, resulting in a pool of 
creativity and talent from more than half the student population being lost to this discipline (Lang, 2007). However, we should never lose sight of the global picture.

Across the world women have grown poorer than before. With their children, women still make up four-fifths of the poorest people in the US and are among the poorest classes throughout the world. (French, 2007, p. viii)

\section{Limitation}

It is difficult to compare statistics across countries as slightly different definitions or interpretations of definitions may have been used in generating the statistics. For example in most countries women who are on paid maternity leave are regarded as still being part of the workforce and included in the employment rates (Abhayaratna \& Lattimore, 2006). However women on unpaid leave are not included in these employment rates. Australia does not yet have legislated minimum paid maternity leave hence comparison of labor rates is difficult.

\section{Acknowledgements}

The authors would like to acknowledging contributions from the ACM-W Ambassadors: Reyyan Ayfer, Turkey; Jehan Ara, Pakistan; Tracy Camp, U.S.A. Co-Chair; Anne Condon, Canada; Vashti Galpin, South Africa; Annike Heinze, New Zealand; Jan Peters, England; M. Suriya, India.

\section{References}

Abhayaratna, J., \& Lattimore, R. (2006). Workforce participation rates - How does Australia compare? Productivity Commission Staff Working Paper, Canberra.

ABS: Australian Bureau of Statistics. (2007a). Australian social trends, Data cube. Cat. 102.0, Canberra: Australian Bureau of Statistics.

ABS: Australian Bureau of Statistics (2007b). Average weekly earnings. Cat. 6302.0, Canberra: Australian Bureau of Statistics.

Allen, M., Castleman, T., Coulthard, \& Reed. (2002). The gender of professional careers for young Australians: Some early findings of a longitudinal study. 2002 ERU Conference; Organising/ Theorising: Developments in the Organizational Theory and Practice, Cardiff.

APESMA. Association of Professional Engineers. (2004). Women in the professions - Survey report 2004. Melbourne.

Byrne, G., \& Staehr, L. (2003). The participation and remuneration of women in the Australian IT industry: An exploration of recent census data. AusWIT 2003 - Participation, Progress and Potential, Hobart, Australia, University of Tasmania.

Charles, M., \& Bradley, K. (2006). A matter of degrees: Female under representation in computer science programs cross-nationally. In J. M. C. W. Aspray, Women and information technology (pp. 183-203). Cambridge, Massachusetts: MIT Press.

Cockburn, C. (1991). In the way of women: Men's resistance to sex equality in organizations. London: Macmillan.

Crompton, R., \& Jones, G. (1984). White collar proletariat. London: Macmillan.

Deery, S., \& Plowman, D. (1985). Australian industrial relations. McGraw-Hill.

Derek Bok Institute for Teaching and Learning. (1996). Sensitivity to women in the contemporary_classroom. Harvard University. Paper presented at Victoria University of Technology. 
European Commission. (2003). She figures 2003: Women and science statistics and indicators. Belgium: Office for Official Publications of the European Communities.

Eveline, J. (1996). The worry of going limp: Are you keeping up in senior management? Australian Feminist Studies, 11(23), 65-79.

Feldman, S. I. (2009). ACM's annual report. Communications of the ACM, 52(1), 33-37.

French, M. (2007). The women's room. Virago.

Hakim, C. (2000). Work-lifestyle choices in the 21st Century. Oxford: Oxford University Press.

Hofstede, G., \& Hofstede, G. J. (2005). Cultures and organizations: Software of the mind. U.S.A.: McGraw-Hill.

IPU: Inter-Parliamentary Union. (2007). Women in national parliaments. Retrieved 11 May, 2007, from www.ipu.org/wmn-e/world.htm

Klawe, M., Whitney, T., \& Simard, C. (2009). Women in computing - Take 2. Communications of the $A C M, 52,68-76$.

Lang, C. (2007). Twenty-first century Australian women and IT: Exercising the power of choice. Computer Science Education, 17(3), 215-216.

Maslog-Levis, K. (2005). Women not taking ICT courses: Academic. ZDNet Australia.

Nielsen, S., \& Von Hellens, L. (2006). The social construction of Australian women in IT. In E. M. Trauth (Ed.), Encyclopedia of gender and information technology (pp. 1105-1111). Hershey PA: Idea Group.

OFW: Office for Women. (2004).Women in Australia 2004. Retrieved December, 2004, from http://ofw.facs.gov.au/publications/wia/chapter4.html

Poole, M. E., \& Langan-Fox, J. (1997). Australian women \& careers: Psychological and contextual influences over the life course. Cambridge: Cambridge University Press.

Probert, B. (2002). 'Grateful slaves' or 'self-made women': A matter of choice or policy? Australian Feminist Studies, 17(37), 7 - 17.

Salvano, S. (1993). Non-traditional occupations- 20 years progress? Networking for the $90 \mathrm{~s}-$ The 2nd Women in Computing Conference 1993, Victoria University, Melbourne.

Spencer, S. (2006). Working from within: Professional societies supporting women in ICT. In J. Fisher (Ed.), Australian Women in IT (AusWIT). Adelaide. www.austwic.org

Summers, A. (2003). The end of equality. Random House.

Suriya, M., \& Craig, A. (2003). Gender issues in the career development of IT professionals: A global perspective. In S. Spencer (Ed.), AusWIT 2003 - Participation, Progress and Potential (pp. 97 - 107). Hobart, Australia, University of Tasmania.

Trauth, E. M. (2002). Odd girl out: An individual differences perspective on women in the IT profession. Information Technology \& People, 15(2), 98-118.

Trauth, E. M. Quesenberry, J., \& Yeo, B. (2006). Environmental context and women in the IT workforce. In E. M. Trauth (Ed.), Encyclopedia of gender and information technology (pp. 276 - 281). Hershey PA: Idea Group.

Watkins, S. A., Rueda, M., \& Rodriguez, M. (1999). Introducing feminism. Cambridge: Icon Books. 


\section{Biographies}

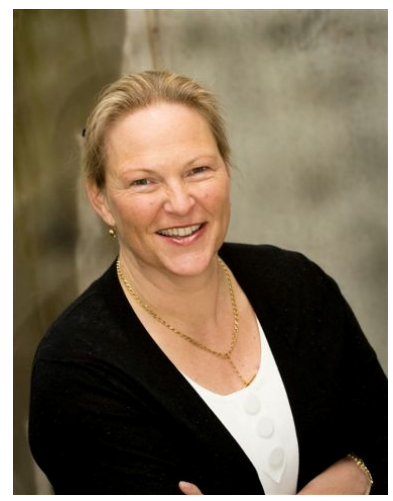

Dr. Annemieke Craig is a Senior Lecturer and Unit Chair in Information Systems in the Faculty of Business and Law. Annemieke's research interests include online learning and the use of technology in teaching in higher education. Annemieke also researches in the fields of access and equity with particular emphasis on trying to improve the profile of women in computing and to encourage more female students to consider computing courses. Annemieke was the Australian Ambassador for the ACM-W from 2000 to 2004 then Co-Chair of the program from 2005 to early 2009.

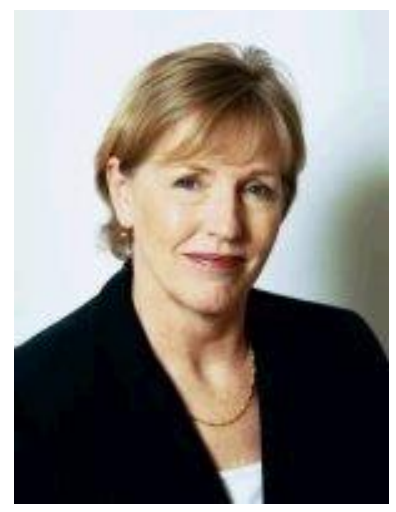

Dr. Catherine Lang is a Senior Lecturer in the Faculty of Information and Communication Technologies. She is currently seconded to the university's Professional Learning Unit working on projects to enhance teaching and learning, student engagement and transition to university. Catherine has been researching the under-representation of women in ICT since 1996 and has held the position of ACM-W Australian Ambassador since 2005. She was a founding Board Member of the Victorian ICT for Women Network and established the Women in ICT group at Swinburne. Her current research project involves "Digital Divas", a curriculum initiative been trialed in secondary schools. 